\title{
The case for a statutory 'definition of death'
}

\author{
P D G Skegg ${ }^{1}$ Faculty of Law, Oxford University
}

Karen Quinlan, the American girl who has lain in deep coma for many months, is still 'alive', that is to say, her heart is still beating and brain death has not occurred. However, several other cases have raised difficult issues about the time of death. Dr Skegg argues that there is a case for a legal definition of death enshrined in statutory form. He suggests that many of the objections to a statutory provision on death are misplaced, and that a statute concerning the occurrence of death could remove all doubts in the minds of both doctors and public as to whether a 'beating heart cadaver' was dead or alive for legal purposes.

There has been little support in the United Kingdom for a statute indicating when a person should be considered dead for legal purposes. For example, a Bar Council report took the view that 'to attempt a legal definition would be at best idle and at worst unnecessarily restrictive' (General Council of the Bar, 197I), and an editorial in the Medico-Legal fournal recently stated that 'a legal definition of death is not feasible' (Thurston, 1975). However a different view is gaining ground in North America (see, eg Compton, 1974; Friloux, 1975), and a reexamination of the matter is clearly desirable.

\section{An examination of the case against legislation}

A great variety of objections have been put forward against the enactment of any provision dealing with the time of death. It has been said that death is a technical, clinical matter, and hence not the proper subject of a statutory provision; that the time of death is not subject to clear-cut definition; and that it would not be possible to provide a definition that would cover all contingencies and be suitable for inclusion in an Act. It has also been said that a statute would be too inflexible and would require amendment in a few years' time; that any statute must await a degree of unanimity on the part of the medical profession; and that independent certification of death provides an adequate safeguard in transplant cases.

A number of these objections result from a failure to recognize the possibility of distinguishing between

${ }^{1}$ Address for correspondence: New College, Oxford OXI 3BN. the point at which death may be deemed to have occurred, and the criteria for determining whethet that point has been reached (see Skegg, 1974). F example, a statute could provide that a persom shall be considered dead when all brain function hạ irreversibly ceased. Such a provision would cover all contingencies, and would be suitable for inclusion in an Act. It would be unlikely to require amendmef in a few years' time, unless it was desired to consmence considering as corpses persons whose total brain function had not irreversibly ceased. So fundamental a change would properly be the subjed of new legislation. An enactment which equated the death of a human being with total brain dea would leave room for the development of new of better criteria for determining when that sta had been reached.

The objection that a statutory enactment must await a degree of unanimity within the medical community is open to question. It could be argues that it is precisely because the medical professio and society at large are not generally agreed as when death may be said to occur that legislation needed. It is, of course, true that legislation shouf prescribe a stage which can be recognized by the medical profession. There would be no point inca statute which simply stated that death was the cess tion of life. Equally, it would be undesirable for statute to refer to irreversible loss of consciousness if there was disagreement as to what is meant this term, or as to how accurately this state couf be recognized. But subject to this, lack of unanimity on the part of the medical profession may be seep as a reason for, rather than against, legislation on this matter.

It is a mistake to think that independent certificat tion of death is an adequate safeguard in transplanit cases. Such certification is highly desirable. But is important that there be agreement as to what it that is to be certified, and such agreement is sometimes lacking at present. Doctors are not all agred whether they may ever treat as dead a body in which the heart continues to beat without artificial meares of support. This matter could be determined ono way or the other by legislation.

\section{The case for legislation}

If the objections to a statutory provision are less than conclusive, what is the case for such legislationg 
Some of the relevant considerations have already been mentioned. The stage in the process of dying at which a person is to be regarded as dead for legal purposes is one of legitimate public interest. Yet at present there are divergent views and practices, and it seems likely that these differences will continue for some time to come.

If no action is taken uncertainty will continue, and doctors may treat as corpses bodies which many would regard as those of living human beings. At present such matters can only be resolved ex post facto. Even then, there is no guarantee that the matter will be clarified for the future. Given the current tendency of English judges to seek to avoid difficult issues by characterizing them as ones of fact, they may simply leave the matter to the jury. Whichever way the jury resolved the matter, its decision would be of very little value for the future.

Whether the matter is treated as one of law or of fact, it is doubtful whether it is best dealt with in the course of a particular dispute. Neither the judge nor the jury is well placed to consider all the relevant considerations. The particular circumstances of the case, and the expert evidence adduced, may be given disproportionate weight. Furthermore, it is unfair to potential litigants that they must go to the expense and emotional exhaustion of court proceedings before they can discover whether a doctor was justified in treating a particular 'beating heart cadaver' as dead. The legitimate interests of both the medical profession and the public are such that there would seem to be a prima facie case for legislation.

\section{An alternative to legislation}

But are there any acceptable alternatives to legislation? It has been suggested (Kennedy, 1976) that what is needed is for 'the new concept of brain death to be incorporated into a code of practice', worked out by the medical profession after consultation with lawyers, theologians and other interested parties, and 'sanctioned by the Ministry of Health'. It was said that such a code would 'serve as an authoritative statement to be followed by doctors and courts alike', and could be kept under review by a permanent standing committee appointed by the Minister. There is much to be said for any attempt to reach an informed consensus of doctors and of the public at large. But unanimity seems unlikely to be achieved in the near future (see, eg, Daily Mail, 8 September 1976, p r), and if achieved will not necessarily continue. Some writers are already arguing that a person is dead when capacity for consciousness has been irreversibly lost, even if brain stem activity continues. When the medical profession and the public are not of one mind as to when a person may properly be considered dead, there is no reason why the courts should feel obliged to treat as authoritative a statement by any committee which has not had law-making powers conferred on it by Parliament. Although it would be open to Parliament to confer on a committee the ?? power to make regulations for determining when a $\vec{F}$ person is to be regarded as dead for legal purposes, $\stackrel{0}{\rightarrow}$ the matter would seem to be too important for Parliament simply to pass to some other body unless, perhaps, strict guidelines had been imposed $\vec{\nabla}$ by Parliament, or the regulations were to require $\propto$ affirmative resolutions of both Houses of Parliament is before coming into force.

\section{A possible enactment}

If there is to be legislation, what form should it take? Ideally, it would apply to all persons, for all iv purposes. It should not be too detailed, but should identify the common factor to which the different $\vec{\theta}$ tests point.

The key provision could state simply that ' $a$ 을 person shall be regarded as dead for legal purposes $\square$ when all bram activity (including brain stem $\mathbb{D}$ activity) has irreversibly ceased'. This provision $\stackrel{\oplus}{\rightarrow}$ would leave the medical profession free to develop new and better criteria for determining when all $\stackrel{\mathbb{S}}{-}$ brain activity had irreversibly ceased, and in this $\vec{\theta}$ context committees of experts would undoubtedly $\sigma$ have a part to play. If this approach were adopted, it might help to reassure some sections of the public if the statute added, ex abundanti cauleta, that the person must be incapable of breathing again without artificial assistance.

If desired, there could be a further provision to the effect that 'the irreversible cessation of brain activity may be deduced from the absence of respiration or circulation for an appropriate period, or by any other means in accordance with good medical practice.' And in view of some of the evidential problems which could arise in litigation (Skegg, $:$ 1974), there might be advantages in also providing 3 that 'where respiration continued with artificial assis- $\delta$ tance, the onus of establishing that the person was $₹$ already dead lies on whoever wishes to rely on that 0 fact.'

\section{Conclusion}

The purpose of this brief article is not to argue in full the case for enacting any particular statute on $N$ death. It is simply to suggest that many of the $\omega$ objections to a statutory provision on death are misplaced, and that there is a strong prima facie case for the enactment of a statute specifying when $a \stackrel{\Phi}{\Phi}$ person should be regarded as dead for legal purposes.

\section{References}

Compton, A C (r974). Telling the time of death by statute: An essential and progressive trend, Washington and Lee Law Review, 31, 52I-543. 
Friloux, C A (1975). Death, When does it occur? Baylor Law Review, 27, I0-2r.

General Council of the Bar (197I). Report of the Law Reform Committee on the Law relating to Organ Transplantation adopted by the Council on 2oth fuly 1971. 16pp., cyclostyled.

Kennedy, I McC (1976). The Karen Quinlan case:
Problems and proposals. Fournal of medicah ethics, 2, 3-7.

Skegg, P D G (1974). Irreversibly comatose individuals 'Alive' or 'dead'? Cambridge Law fournal, 33, 130-144.

Thurston, G (1975) Editorial, The beating-hearf cadaver. Medico-Legal fournal, 43, 37-38. 